\title{
Tes serologi dan polimerase chain reaction (PCR) untuk deteksi SARS-CoV-2/COVID-19
}

\author{
Pusparini \\ Departemen Patologi Klinik, Fakultas Kedokteran Universitas Trisakti, Indonesia \\ Email: pusparini@trisakti.ac.id
}

Penyebaran penyakit virus corona 2019 (COVID-19) di dunia meningkat sangat cepat, sehingga oleh World Health Organization (WHO) dinyatakan sebagai suatu pandemi global. Pada kondisi pandemi ini, lansia dan populasi yang rentan perlu mendapat perlindungan dari penyebaran COVID-19. Sebagian besar individu yang terinfeksi virus severe acute respiratory syndrome coronavirus 2 (SARS-CoV-2) tidak menunjukkan gejala atau hanya bergejala ringan sampai sedang, dengan gejala mirip flu atau infeksi flu lainnya, sehingga bila kita kehilangan kemampuan untuk mengikuti jejak semua orang yang pernah terinfeksi SARS-CoV-2 maka proses identifikasi individu yang potensial terinfeksi akan menjadi sulit. Untuk dapat memproteksi populasi yang rentan maka diperlukan status dari seseorang yang pernah kontak dengan pasien COVID-19 secara cepat. ${ }^{(1)}$

Pemeriksaan laboratorium memegang peranan penting untuk menentukan status seseorang terkait dengan infeksi COVID-19. Virus SARS-CoV-2 merupakan virus baru, sehingga pengertian dan interpretasi yang tepat mengenai penggunaan tes laboratorium untuk diagnosis penyakit coronavirus sangat diperlukan. Terdapat dua kategori tes laboratorium untuk mendeteksi SARS-CoV-2 yaitu tes untuk mendeteksi virusnya sendiri dan mendeteksi respons dari host. Masing-masing tes mempunyai keunggulan dan kekurangan. $^{(2)}$

Saat ini tes standar untuk deteksi SARSCoV-2 adalah SARS-CoV-2 real time reverse transcription quantification polimerase chain reaction (RT-PCR) menggunakan sampel bahan swab nasofaring atau orofaring, sputum atau cairan bilas bronkial (bronkhial lavage). Penggunaan RT-PCR memerlukan protokol standar antara lain ribo nucleic acid (RNA) harus diekstraksi dan adanya virus RNA dikonfirmasi dengan RT-PCR ${ }^{(2)}$
Ada beberapa gen target yang digunakan untuk mendeteksi SARS-CoV-2 yaitu gen E (Envelope), gen $\mathrm{N}$ (nukleokapsid), gen $\mathrm{S}$ (Spike) dan gen RdRp. $^{(3,4)}$ Pasien disebut terkonfirmasi COVID-19 bila pada deteksi dengan RT-PCR ditemukan urutan unik dari RNA virus. Hasil positif RT-PCR menunjukkan bahwa kemungkinan seseorang terinfeksi COVID-19, sedangkan hasil negatif belum dapat menyingkirkan seseorang terinfeksi COVID-19. Pemeriksaan RT-PCR untuk SARSCoV-2 saat ini merupakan tes kualitatif dan sampai sekarang belum ada standarisasi untuk menentukan ambang batas viral load pada host yang berbeda-beda. ${ }^{(3)}$

Pada daerah yang tidak ada laporan, adanya infeksi dengan SARS-CoV-2 maka pemeriksaan dengan RT-PCR disebut positif harus memenuhi kriteria berikut: 1) tes positif nucleic acid amplification test (NAAT) harus berasal dari dua target gen yang berbeda dengan salah satu target gen merupakan gen yang spesifik untuk virus COVID-19 (N, RdRp) atau; 2) menggunakan satu target gen positif dan dilanjutkan identifikasi dengan sekuensing sebagian atau seluruh genom dari virus sepanjang sekuens target lebih besar atau berbeda dengan probe amplicon pada yang digunakan di tes NAAT. Jika terdapat hasil yang berbeda maka harus dilakukan pengambilan sampel ulang. Pada individu yang dicurigai terinfeksi COVID-19, tetapi hasil RT-PCR-nya negatif, hal berikut patut dipikirkan antara lain: 1) kualitas spesimen yang buruk atau hanya mengandung sangat sedikit sampel; 2) virus tidak terdapat pada tempat sampel diambil; 3) spesimen diambil pada fase infeksi yang tidak tepat seperti terlalu lambat atau terlalu cepat; 4) penanganan spesimen tidak baik; 5) adanya mutasi virus dan inhibisi PCR. ${ }^{(3,5)}$ Hal-hal tersebut yang mendasari mengapa hasil RT-PCR yang negatif memerlukan sampel ulangan beberapa hari kemudian untuk 
mengurangi adanya individu yang terinfeksi tetapi tidak terdeteksi. ${ }^{(5)}$ Beberapa hal yang memengaruhi hasil RT-PCR untuk SARS-CoV-2 adalah sensitifitas dan spesifitas tes yang digunakan, tipe sampel yang digunakan, waktu pengambilan, target gen yang digunakan (satu atau multipel), dan kemungkinan adanya mutasi virus. ${ }^{(2)}$ Pasien dalam fase penyembuhan (sudah dua kali tes NAAT negatif) harus tetap diperiksa secara regular dan melakukan karantina mandiri di rumah selama 14 hari karena ada bukti yang menunjukkan bahwa pasien tersebut masih mungkin menjadi positif kembali pada tes berikutnya. ${ }^{(6)}$

Tes dengan dasar respons dari host adalah dengan menggunakan tes serologi untuk mendeteksi adanya Ig M, Ig A, Ig G atau antibodi total terutama dari sampel darah. Pembentukan respons antibodi terhadap infeksi sangat tergantung dari respons host dan biasanya memerlukan waktu untuk terdeteksi. Pada SARS-CoV-2 dilaporkan mayoritas pasien mengalami serokonversi antara hari ke-7 sampai ke-14 pasca terpapar virus, walaupun ada beberapa pasien yang dapat membentuk antibodi lebih awal. Dengan adanya proses pembentukan antibodi seperti di atas maka penggunaan tes dengan dasar antibodi kurang bermanfaat untuk digunakan pada kondisi penyakit akut. ${ }^{(2)}$ Penelitian sebelumnya menunjukkan IgM muncul hari ke-7, meningkat sampai hari ke-28 dan mulai menurun pada hari ke-42, sedangkan IgG muncul hari ke-10, meningkat sampai hari ke49. Kadar antibodi IgM dan IgG lebih tinggi pada pasien dengan klinis berat dibandingkan pasien dengan klinis ringan. ${ }^{(7)}$

Penelitian lainnya menunjukkan penggunaan tes antibodi atau tes rapid untuk deteksi adanya SARS-CoV-2 memperlihatkan sensitifitas rendah yaitu $36.4 \%$ dan spesifisitas $88.93 \%$. Hal ini menunjukkan bahwa dari pasien dengan hasil RT-PCR positif hanya $36.4 \%$ yang menunjukkan tes antibodi positif dan dari pasien dengan hasil RT-PCR negatif ditemukan bahwa terdapat $88.93 \%$ pasien yang menunjukkan hasil tes antibodi negatif juga. Atas dasar tersebut maka tes antibodi tidak direkomendasikan untuk digunakan untuk skrining di komunitas. ${ }^{(1)}$ Penggunaan tes antibodi atau serologi digunakan untuk melakukan investigasi terhadap kejadian luar biasa yang sedang terjadi (ongoing outbreak) dan pemeriksaan retrospektif terhadap attack rate. Pada kondisi hasil tes NAAT negatif dan terdapat bukti epidemiologi yang kuat mengenai paparan terhadap infeksi COVID-19, maka dapat digunakan serum pasangan pada fase akut (minggu pertama sakit) dan fase convalescent (2-4 minggu kemudian) untuk mendukung diagnosis. ${ }^{(3)}$

Pada penanganan COVID-19 di Indonesia tes rapid antibodi dan/atau antigen dapat digunakan pada orang tanpa gejala (OTG) atau kasus kontak dari pasien konfirmasi COVID-19. Selain itu, dapat juga digunakan untuk deteksi kasus orang dalam pemantauan (ODP) dan pasien dalam pengawasan (PDP) pada wilayah yang tidak mempunyai fasilitas RT-PCR atau tidak mempunyai media pengambilan spesimen (swab dan virus transport media /VTM). Tes rapid antibodi atau antigen hanya merupakan tes awal dan hasil pemeriksaannya tetap harus dikonfirmasi dengan RT-PCR. ${ }^{(8)}$ Pembacaan tes rapid antibodi harus disesuaikan dengan waktu yang tertera pada kit insert masing-masing reagensi yang digunakan, walaupun hasil samar tetap ditulis sebagai reaktif asal masih dalam rentang waktu pembacaan. Hasil rapid tes antibodi dinyatakan dengan reaktif atau tidak reaktif. Tes reaktif artinya terdapat hasil anti SARS-CoV-2 IgM reaktif, anti SARS-CoV-2 IgG non reaktif, atau anti SARS-CoV-2 IgM non reaktif, anti SARS-CoV-2 IgG reaktif, atau anti SARS-CoV-2 IgM dan IgG reaktif atau anti SARSCoV-2 antibodi total reaktif sedangkan disebut hasil tes rapid antibodi non reaktif bila ditemukan hasil tes anti SARS-CoV-2 IgM dan IgG non reaktif atau anti SARS-CoV-2 antibodi total non reaktif. Hasil non reaktif tidak menyingkirkan kemungkinan terinfeksi SARS-CoV-2, sehingga masih berisiko menularkan ke orang lain. Hasil non reaktif dapat terjadi pada kondisi 1) seseorang belum atau tidak terinfeksi; 2) periode jendela (terinfeksi namun antibodi belum terbentuk); dan 3) imunokompromais; serta 4) kadar antibodi dibawah level deteksi alat. ${ }^{(9)}$

\section{REFERENSI}

1. Döhla M, Boesecke C, Schulte B, et al. Rapid point-of-care testing for SARS-CoV-2 in a community screening setting shows low sensitivity. Public Health 2020;182:170-2. doi: 10.1016/j. puhe.2020.04.009.

2. Patel R, Babady E, Theel E, et al. Report from the American Society for Microbiology COVID-19 COVID-19. MBio 2020;11(2):1-5. doi: 10.1128/ mBio.00722-20.

3. World Health Organization. Laboratory testing of 
2019 novel coronavirus (2019-nCoV) in suspected human cases: interim guidance, 17 January 2020 [Internet]. World Health Organization; 2020. Available from: https://apps.who.int/iris/ handle/10665/330676

4. Corman VM, Landt O, Kaiser M, et al. Detection of 2019-nCoV by RT-PCR. Euro Surveill. 2020;25(3):pii=2000045. doi: 10.2807/1560-7917. ES.2020.25.3.2000045

5. Green K, Winter A, Dickinson R, et al. What tests could potentially be used for the screening, diagnosis and monitoring of COVID-19 and what are their advantages and disadvantages? [Internet]. Oxford: Centre for Evidence Based Medicine. 2020. Available from: https://www.cebm.net/ covid-19/what-tests-could-potentially-be-usedfor-the-screening-diagnosis-and-monitoring-ofcovid-19-and-what-are-their-advantages-anddisadvantages/

6. Chen D, Xu W, Lei Z, et al. Recurrence of positive SARS-CoV-2 RNA in COVID-19: A case report. Int J Infect Dis 2020;93:297-9. doi: 10.1016/j. ijid.2020.03.003.

7. Tan W, Lu Y, Zhang J, et al. Viral Kinetics and Antibody Responses in Patients with COVID-19. medRxiv 2020;2020.03.24.20042382. doi: $10.1101 / 2020.03 .24 .20042382$

8. Kemenkes RI. Pedoman Pencegahan dan Pengendalian Coronavirus Disease (COVID-19) [Internet]. Jakarta: Direktorat Jenderal Pencegahan dan Pengendalian Penyakit. 2020. Available from: https:/covid19.go.id/p/protokol/pedomanpencegahan-dan-pengendalian-coronavirusdisease-covid-19

9. Perhimpunan Dokter Spesialis Patologi Klinik dan Kedokteran Laboratorium Indonesia. Panduan tatalaksana pemeriksaan rapid test antibody SARS-CoV-2 metode imunokromatografi [Internet]. Jakarta: PDS PatKLIn. 2020. Available from: https://www.pdspatklin.or.id/assets/files/ pdspatklin_2020_03_25_17_58_47.pdf 